\title{
Response to somatic cell count-based selection for mastitis resistance in a divergent selection experiment in sheep
}

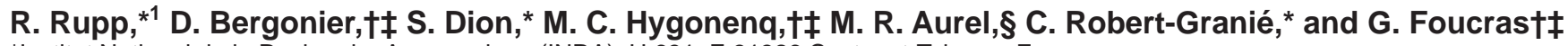 \\ *Institut National de la Recherche Agronomique (INRA), U 631, F-31326 Castanet-Tolosan, France \\ †INRA, Unité Mixte de Recherche (UMR) 1225, F-31076 Toulouse, France \\ łUniversité de Toulouse, École Nationale Vétérinaire de Toulouse (ENVT), UMR 1225, F-31076 Toulouse, France \\ §INRA, UE 321, F-12250 Roquefort, France
}

\section{ABSTRACT}

A divergent selection experiment in sheep was implemented to study the consequences of log-transformed somatic cell score (SCS)-based selection on resistance to natural intramammary infections. Using dams and progeny-tested rams selected for extreme breeding values for SCS, we created 2 groups of ewes with a strong divergence in SCS of approximately 3 genetic standard deviations. A survey of 84 first-lactation ewes of both the High and Low SCS lines indicated favorable responses to SCS-based selection on resistance to both clinical and subclinical mastitis. All clinical cases $(\mathrm{n}=5)$ occurred in the High SCS line. Additionally, the frequency of chronic clinical mastitis, as detected by the presence of parenchymal abscesses, was much greater in the High SCS line $(\mathrm{n}=21)$ than in the Low SCS line $(\mathrm{n}=1)$. According to monthly milk bacteriological examinations of udder halves, the prevalence of infection was significantly greater (odds ratio $=3.1$ ) in the High SCS line than in the Low SCS line, with predicted probabilities of 37 and $16 \%$, respectively. The most frequently isolated bacteria responsible for mastitis were staphylococci: Staphylococcus auricularis (42.6\% of positive samples), Staphylococcus simulans, Staphylococcus haemoliticus, Staphylococcus xylosus, Staphylococcus chromogenes, Staphylococcus lentus, Staphylococcus warneri, and Staphylococcus aureus. The incidence of positive bacteriology was greater in the High SCS line (39\%) than in the Low SCS line (12\%) at lambing, indicating that High SCS line ewes were especially susceptible to postpartum subclinical mastitis. Negativation of bacteriological results from one sampling time point to the next was markedly different between lines after weaning (e.g., 41 and $84 \%$ in the High and Low SCS lines, respectively). This result was consistent with differences in the duration of infection,

Received June 9, 2008.

Accepted October 16, 2008

${ }^{1}$ Corresponding author: Rachel.Rupp@toulouse.inra.fr which was much greater in the High SCS line compared with the Low SCS line. Finally, ewes from the High SCS line consistently had greater SCS in positive milk samples than did ewes from the Low SCS line $(+2.04$ SCS, on average), with an especially large difference between lines during the suckling period (+3.42 SCS). Altogether, the preliminary results suggest that the better resistance of Low SCS line ewes, compared with High SCS line ewes, was principally characterized by a better ability to limit infections during the peripartum period, to eliminate infections during lactation, and quantitatively to limit the inflammation process and its clinical consequences.

Key words: mastitis, somatic cell count, divergent selection, dairy sheep

\section{INTRODUCTION}

On an international level, improving the health of livestock is of dramatically increasing interest to the dairy industry and consumers (Stear et al., 2001). Among the infectious diseases, mastitis is of major importance because of its high frequency and related costs in dairy ruminants. Furthermore, some of the classical prophylactic measures sometimes appear too demanding to breeders in terms of time and care, and efficient vaccination against the main pathogens is still lacking; thus, complementary strategies are needed. There is accumulating evidence, however, that the highly successful selection for milk production achieved over recent decades has led to a deterioration of mastitis resistance (Emanuelson et al., 1988; Heringstad et al., 2003a; Carlen et al., 2004). Accordingly, many countries (Heringstad et al., 2000; Miglior et al., 2005) have recently updated their breeding objective to include or increase the weight for nonproductive traits, with special attention given to mastitis resistance. Currently, selection strategies are based on a linear decrease of milk SCS, ideally as a tool to decrease both subclinical and clinical IMI. Scandinavian countries, where a large-scale recording scheme for clinical mastitis (CM) 
is available, also directly include the reduction of $\mathrm{CM}$ as a selection criterion (Heringstad et al., 2003b).

Milk SCC mainly reflects the number of neutrophils that migrate from blood to the mammary gland in response to IMI. Measured on a monthly basis, it can therefore be interpreted as an effect of infection and a good indirect indicator of chronic mastitis. To achieve data normality, SCC are commonly log-transformed to SCS (Ali and Shook, 1980). Genetic correlation between SCS and bacterial infection was estimated to be near unity in the only available large-scale study $(9,784$ recorded cows; Weller et al., 1992), indicating that SCS and subclinical infections are essentially the same trait. Additionally, there is evidence that SCS-based selection should efficiently reduce CM incidence. The genetic correlation between SCS and CM is high, ranging from 0.60 to 0.70 (Heringstad et al., 2000, 2006; Carlen et al., 2004; Koivula et al., 2005). Furthermore, the correlation between SCS and CM does not show any sign of nonlinearity (McDaniel and Adkinson, 1993; Philipsson et al., 1995; Rupp et al., 2000; Cranford and Pearson, 2001), and 2 studies reported that the cows with the lowest observed SCC were cows with the lowest risk of CM (Rupp et al., 2000). The advantage of using SCS rather than $\mathrm{CM}$ directly in selection relies on greater heritability (e.g., 0.15 vs. 0.02 , on average) on a linear scale (Heringstad et al., 2003b; Rupp and Boichard, 2003). Furthermore, only Scandinavian countries have recording schemes for CM for many years. In those countries, where CM is also included in the selection index, the low heritability of $\mathrm{CM}$ is counterbalanced by the large size of the progeny groups to obtain high accuracy of the breeding values of a sire.

However, data are lacking on the genetic relationships between SCC or SCS, CM, and IMI across the environment and over time, and on the field evolution of IMI frequencies as a result of SCS- or CM-based breeding schemes. Both SCS and CM are used as a phenotypic black box selection tool that might not fully consider the variety of pathogens responsible for mastitis and the complexity of the resistance traits. There is little knowledge of the genes and mechanisms mobilized by phenotype-based selection. To our knowledge, only the Norwegian data clearly demonstrate the efficiency of selection against mastitis (Heringstad et al., 2007). In Norway, CM is a priority in the breeding objective, and it (and not SCS) is explicitly included as a selection criterion. The estimated annual genetic trend has been approximately $-0.25 \% \mathrm{CM}$ frequency in recent years (Heringstad et al., 2003b). A long-term divergent selection experiment using AI bulls confirmed this result and showed a $10 \%$ decrease in $\mathrm{CM}$ incidence attributable to selection against $\mathrm{CM}$ after 5 generations (Heringstad et al., 2007). The long-term effects and efficacy of sole-
SCS selection, however, are still unknown. A better understanding of the defense mechanisms affected and modified by SCS-based selection would be helpful to predict the indirect response for $\mathrm{CM}$, pathogen-specific infections, and resistance to other diseases in the long term.

The objective of this study was to evaluate the consequences of SCS-based selection on the resistance of the host to IMI. The experiment was based on a onegeneration divergent selection of dairy ewes, using the ovine species as a model to study mastitis resistance. This paper reports on the animal design and preliminary results acquired during the close follow-up of the 2 High and Low SCS lines during their first lactation.

\section{MATERIALS AND METHODS}

\section{Animals}

A one-generation divergent selection of Lacaune dairy ewes based on EBV for milk SCS of dams and sires was initiated in 2003 at the INRA experimental facility of La Fage (UE 321, Roquefort, France). Individual EBV based on the lactation mean of SCS [SCS $=3+\log _{2}(\mathrm{SCC} / 100,000)$; Ali and Shook, 1980], were obtained from the national genetic evaluation scheme implemented in the French Lacaune breed since 2002, as described previously (Rupp et al., 2002). Estimated breeding values were expressed as standard deviations, reversing the sign so that positive EBV were desirable (low SCC).

Two groups of 7 progeny-tested rams, that is, approximately $10 \%$ of rams with reliable (reliability $\geq 0.70$ ) and extreme EBV for SCS, were used to sire female offspring of 2 lines, designated as the Low and High SCS lines. Sires of the High SCS line had SCS EBV less than -1.80 , and sires selected for the Low SCS line had SCS EBV greater than 1.30, with a mean selection intensity of 1.90 (mean and SD of the whole ram EBV were 0.03 and 0.79 , respectively). Furthermore, rams were required to show similar and favorable EBV (ram population mean $\mathrm{EBV} \pm 0.5 \mathrm{SD}$ ) for milk production to avoid confounding effects from an indirect response to selection for production traits. Ewes of the INRA flock were split into 2 groups according to their SCS EBV so that a moderate selection intensity of 0.8 was also applied to dams. Each selected sire was mated with approximately 13 ewes of the corresponding High or Low SCS group, and a total of 114 female offspring were obtained. The latter 114 ewes were inseminated at approximately 8 mo of age. A total of 84 ewes, 46 in the High SCS line and 38 in the Low SCS line, began a first lactation at the INRA experimental facility, and 78 of them had at least one test-day record. 
Ewes in both lines were housed together in the same physical area and managed identically. In particular, they were machine-milked altogether, without a predefined milking order. The whole flock included 500 Lacaune ewes, which were milked once a day from 24 $\mathrm{h}$ postpartum to weaning and twice a day after the 28-d suckling period. They were maintained on diurnal pasture for the second period of their first lactation from April to August, at the end of which they were dried off. Finally, feeding, machine milking, and housing were totally representative of the regional breeding system of the Roquefort area. No voluntary culling took place during lactation or at drying off for divergent line animals, except for 2 groups of 9 healthy High and Low SCS line ewes (according to bacteriological milk examination and SCC, respectively) that were removed from the flock at the beginning of their lactation for further investigation (experimental infections, etc.).

\section{SCC and Milk Production Traits}

Recordings of milk production and SCC were performed as part of the official milk recording of the flock. Milk production and SCC were measured every $3 \mathrm{wk}$ (i.e., at 8 time points from February to June 2005). In general, the first test-day record was done during the suckling period. The proportions of High and Low SCS line ewes recorded while suckling their lambs were 100,16 , and $10 \%$ for the first 3 milk-recording time points, respectively. Both udder-half foremilk samples and composite milk samples from each ewe at the morning milking were used to perform SCC with a Fossomatic cell counter (Foss, Nanterre, France) at the Interprofessional Milk Analysis Laboratory (Aurillac, France). Milk production traits recorded were test-day milk yield, and fat and protein contents at the morning milking.

\section{Udder-Half Infection Status}

Milk Bacteriological Examination. Milk samples from individual udder halves were collected just after lambing (and before the first suckling) and then concomitantly with the 8 SCC samples (the day before) at the beginning of the morning milking. Before sampling, teats were disinfected with gauze soaked in a $70 \%$ alcohol solution after elimination of the foremilk. Milk samples were immediately frozen for later analysis. Bacteriological analyses were performed at the Veterinary School of Toulouse (UMR 1225 laboratory) by conventional techniques according to International Dairy Federation (1981) guidelines, with a few additions. Briefly, after overnight thawing in a refrigerator, samples were homogenized and assessed visually, and $100 \mu \mathrm{L}$ was plated onto trypticase soy agar enriched with $5 \%$ sheep blood (BioMérieux, Marcy L'Étoile, France). In addition, 100 $\mu \mathrm{L}$ of sample was inoculated into a brain-heart infusion broth (BioMérieux), which was plated onto trypticase soy agar after an overnight incubation. All plates were incubated in a normal atmosphere and then in a $\mathrm{CO}_{2}-$ enriched atmosphere at $37^{\circ} \mathrm{C}$. They were examined at d 1, 2, and 3 after plating. Colonies in a pure or mixed ( 2 bacterial types) culture were enumerated and then identified (cultures with 3 bacterial types or more were considered contaminated). Colonies were characterized morphologically and patterns of hemolysis were recorded. After cloning, gram-positive, catalase-positive cocci were submitted to DNase and tube coagulase tests and to the API ID32 microtube identification system (BioMérieux), according to the instructions of the manufacturer. Other organisms, presumptively streptococci, corynebacteria, and enterobacteria after gram staining, morphology examination, and catalase or oxydase tests, were also submitted to the respective API identification systems in the same conditions. The results were interpreted by using APILAB Plus software (BioMérieux). All identified strains were stored at $-80^{\circ} \mathrm{C}$.

Molecular Identification of Mastitis Pathogens. The API microtube system results were not interpretable when 1) the identification confidence level according to the APILAB Plus software was too low ("unacceptable" species identification or identification at the genus level only); or 2) very few biochemical tests gave clear positive reactions after the recommended incubation time ("silent" biochemical profiles: no valid identification at the species or at the genus level). In these 2 cases, 16S rRNA gene sequencing was performed to identify these strains definitively at the species level, and subsequently to correctly interpret series of consecutive positive bacteriological results of the same genus from one udder half. A total of 50 strains of CNS and 6 strains of streptococci were sequenced. Briefly, total crude DNA from bacteriological cultures was extracted in a proteinase $\mathrm{K}$ lysis buffer. The whole $16 \mathrm{~S}$ rRNA genes were amplified by PCR, using the forward primer W17 and the universal reverse primer W02 in Escherichia coli positions 3 to 22 and 1,509 to 1,492, respectively (Godon et al., 1997). The PCR conditions were as follows: an initial denaturation step at $94^{\circ} \mathrm{C}$ for $2 \mathrm{~min}$, followed by 30 cycles of a 3-stage program with $30 \mathrm{~s}$ at $94^{\circ} \mathrm{C}, 30 \mathrm{~s}$ at $50^{\circ} \mathrm{C}$, and $2 \mathrm{~min}$ at $72^{\circ} \mathrm{C}$, and a final elongation step running for $5 \mathrm{~min}$ at $72^{\circ} \mathrm{C}$. The PCR products were controlled by $1 \%$ agarose gel electrophoresis and were purified with QIAquick purification kits, in accordance with the instructions of the manufacturer (Qiagen, Courtaboeuf, France). Purified 16S rRNA genes were sequenced by using the previously described reverse universal primer 
W31 (Snell-Castro et al., 2005) to obtain the initial 500 bp. The reaction sequences were obtained by using a BigDye Terminator v3.1 cycle sequencing kit (Applied Biosystems, Courtaboeuf, France). The sequence reaction products were analyzed by using an automated capillary 3100 sequencer (Applied Biosystems), following the instructions of the manufacturer. Sequences were identified by comparison with sequences available in the GenBank database by using the Basic Local Alignment Search Tool (BLAST) program (Altschul et al., 1997). Sequences with a percentage similarity of $97 \%$ or greater were considered to represent the same species.

Processing of Bacteriological Results. After conventional bacteriological identification and sequencing, a total of 1,122 bacteriological results were available across the 9 sampling time points. To process this information, the following binary traits pertaining to instantaneous bacteriological results were defined:

- A positive result was defined as a pure culture (or a culture of 2 bacterial types at maximum) obtained from a half-udder milk sample directly or after broth enrichment, whereas a negative result was defined as the absence of bacteriological culture (even after enrichment) from a half-udder milk sample (BAC).

- A new bacteriologically positive result was defined as a positive result given that the previous result on the same half udder was negative. Udder halves were presumed to be negative before first lambing (newBAC).

- A negativation was defined as a bacteriologically negative result given that the previous result on the same half udder was positive. Negativation was therefore calculated only from sampling time points 2 (suckling period) to 9 (negBAC).

To take into account the dynamics of infection(s) of a given udder half over the whole lactation, additional IMI characterizations were considered for 60 animals (120 udder halves) that were collected during the whole sampling time period (9 time points). For each udder half, the number of different successive specific infections (e.g., with different bacterial species) was calculated, as well as their duration. The duration was estimated by the number of successive isolations of the same species, including the possibility of shedding intermittences.

\section{CM and Mammary Examination}

Peracute to subacute CM was systematically recorded by experienced technicians of the flock. Detection was based on general (fever, exhaustion, loss of appetite) and local signs. The latter were usually observed at milking: color or consistency-modified milks, and hot, swollen, or painful udders. Aseptic milk samples of diseased animals were collected and transferred to the Veterinary School of Toulouse (UMR 1225 laboratory) for bacteriological examination (performed according to the same conventional methods).

In addition, mammary clinical evaluations of the High and Low SCS line ewes were performed by trained technicians from the experimental farm. The aim was to detect the signs of chronic mastitis systematically and to differentiate them from noninfectious mammary abnormalities or conformation peculiarities. Recorded observations included the presence of abscesses, diffuse hardness, udder unbalance, and infectious dermatitis (compatible with Staphylococcus aureus impetigo). Lacteal cysts were recorded and differentiated from abscesses. Mammary inspections and palpations took place at 4 time points during the lactation: before (udder balance) and after (others) the morning milking, at approximately $1,2,3$, and 4 mo after lambing. A total of 225 mammary examinations of 72 ewes were available at the end of the study period.

\section{Statistical Analyses}

Method. Linear mixed models (PROC MIXED, SAS Institute Inc., Cary, NC) were used to evaluate the effect of line on the different repeated continuous traits: test-day SCS and production traits from composite total milk samples, and test-day SCS from udder halves (SCSuh).

Mixed logistic models for binary data using the GLIMMIX macro of SAS (Wolfinger and O'Connell, 1993) were fitted to analyze the effect of line on repeated results of infection status traits as defined above (see Processing of Bacteriological Results section): an instantaneous bacteriological result (BAC), a new bacteriological positive result (whatever the species) after a negative result (newBAC), and negativation (negBAC) as measured for each udder half. The macro uses iteratively reweighted likelihoods to fit the generalized linear mixed model. Models were fitted with a logistic link function and a binomial error. To assess statistical differences between lines on traits with low frequencies and smaller data sets (mammary examination, BAC with specific bacterial species, duration of infections), Fisher's exact tests (PROC FREQ, SAS Institute Inc.) were computed.

General Form of the Models. Models for all traits were within the class of regression models and can be written in a general form as follows:

$$
\mathbf{y}=\mathbf{X} \beta+\mathbf{Z a}+\mathbf{e},
$$


Table 1. Covariance matrix structure tested for random animal $(\mathbf{G})$ and residual $(\mathbf{R})$ effects

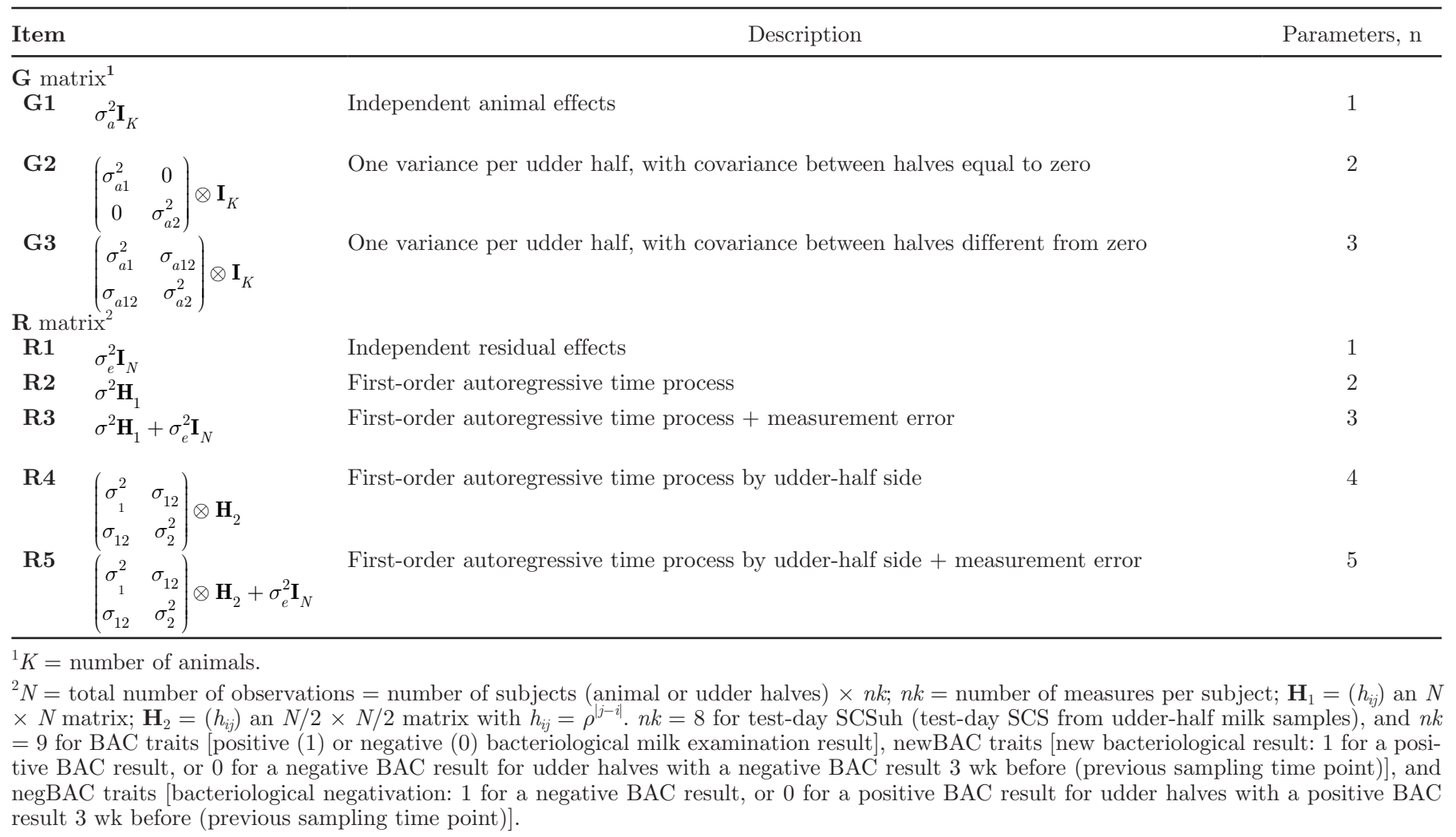

where $\mathbf{y}$ is the vector of measures for test-day SCS, SCSuh, milk yield, fat and protein contents, BAC, new$\mathrm{BAC}$, and negBAC; $\beta$ is the vector of fixed effects; $\mathbf{a}$ is the random animal effect; and $\mathbf{e}$ is the random vector of residual effects. $\mathbf{X}$ and $\mathbf{Z}$ are the incidence matrices linking phenotypic measurements to fixed effects $\beta$ and subjects a, respectively. It is assumed that $\mathbf{a} \sim N(\mathbf{O}$, $\mathbf{G})$, where $\mathbf{G}$ is the subject covariance matrix, and $\mathbf{e}$ $\sim N(\mathbf{O}, \mathbf{R})$, where $\mathbf{R}$ is the residual covariance matrix. Accordingly, $\operatorname{var}(\mathrm{y})=\mathbf{Z G} \mathbf{Z}^{\prime}+\mathbf{R}$.

In a first step, for each trait, a variance-covariance matrix was assumed and a model for the mean was chosen by selecting fixed effects via the robust estimators proposed by Liang and Zeger (1986). After selection of the fixed effects, the second step consisted of selecting and testing several covariance structures for animal and residual effects, following the strategy and methodology used by Robert-Granie et al. (2004). To account for the correlation of measures within subjects (longitudinal recording), $5 \mathbf{R}$ matrix covariance structures were tested (Table 1). The latter included a first-order autoregressive process with or without additional observational error. For traits measured for each udder half (SCS and bacteriological results), modeling the covariance structure of the random animal part ( $\mathbf{G}$ matrix) aimed at testing different variances for each udder half and the correlation between udder halves (Table 1). Selection of the best models was based on the Akaike criteria for nonnested models and on the likelihood ratio test when models were nested, as proposed by Robert-Granie et al. (2004).

Models for Test-Day SCS and Production Traits Measured on Composite Milk Samples. For test-day SCS and milk, fat, and protein contents, the environmental fixed effects tested were the following: line, lambing week (4 classes), number of suckled lambs, sampling time point, and all interactions between these factors. Sampling time point was grouped into 8 levels (sampling during suckling period +7 test dates during exclusive milking). The correlated structure of data within animals arising from longitudinal measurements (8 sampling time points) was fitted with a first-order autoregressive covariance structure on residuals (R2), and independent animal effects (G1) as described in Table 1. Accordingly, the correlation between test days $i$ and $j$ within animals can be written as

$$
r_{i j}=\frac{\sigma_{a}^{2}+\rho^{\left|t_{j}-t_{j}\right|} \sigma^{2}}{\sigma_{a}^{2}+\sigma^{2}},
$$


where $\sigma_{a}^{2}$ is the animal variance, $\rho$ is the autocorrelation parameter, and $\sigma^{2}$ is the variance of the autoregressive process.

Models for Test-Day SCS Measured on Udder Halves. The availability of test-day SCS measured from each of the 2 udder halves allowed us to evaluate the effect of bacteriological status of the udder half in addition to the effect of the line, when compared with the model for composite milk SCS. Accordingly, the environmental fixed effects tested were the following: line, lambing week (4 classes), number of suckled lambs, sampling time point (8 levels as defined earlier), udder-half side, and bacteriological result concomitant with the test-day SCS measure on the same half udder (2 classes: negative vs. positive). All second- and third-order interaction terms between fixed effects were tested.

To account for the correlated structure of test-day SCS between and within udder halves, the best model (as mentioned above) among those tested (Table 1) included a single-animal variance for the $\mathbf{G}$ matrix $(\mathbf{G} \mathbf{1})$ and a first-order autoregressive time process by udderhalf side plus a measurement error for the residual $\mathbf{R}$ matrix (R5). Accordingly, correlation between test days $i$ and $j$ within an udder half $l$ can be written as

$$
r_{i j}=\frac{\sigma_{a}^{2}+\rho^{\left|t_{i}-t_{j}\right|} \sigma_{l}^{2}}{\sigma_{a}^{2}+\sigma_{l}^{2}+\sigma_{e}^{2}},
$$

where $\sigma_{a}^{2}$ is the animal variance, $\rho$ is the autocorrelation parameter, $\sigma_{l}^{2}$ is the variance of the autoregressive process for side $l$, and $\sigma_{e}^{2}$ the measurement error variance. The correlation between test-day SCS from the left and right sides at a given time point is

$$
r_{\text {right-left }}=\frac{\sigma_{a}^{2}+\sigma_{12}}{\prod_{l} \sqrt{\sigma_{a}^{2}+\sigma_{l}^{2}+\sigma_{e}^{2}}},
$$

where $\sigma_{12}$ is the residual covariance between left and right test-day SCS.

Models for Bacteriological Status Traits. For bacteriological status traits (BAC, newBAC, and negBAC), the environmental fixed effects tested were the following: line, lambing week (4 classes), number of suckled lambs, sampling time point, udder-half side, and all interactions between these factors. The 9 sampling time points (lambing, suckling period +7 test days during exclusive milking) were grouped into 6 classes (lambing; suckling; test-day 3; test-days 4 and 5; test-days 6 and 7; test-days 8 and 9) to allow sufficient positive bacteriological results by class for parameter estimation.

Best covariance structure combinations were $\mathbf{G 2}$ and R5 for BAC and G1 and R3 for newBAC and negBAC (Table 1). For BAC, correlation between test days $i$ and $j$ within an udder half $l$ can be written as

$$
r_{i j}=\frac{\sigma_{a l}^{2}+\rho^{\left|t_{i}-t_{j}\right|} \sigma_{l}^{2}}{\sigma_{a l}^{2}+\sigma_{l}^{2}+\sigma_{e}^{2}},
$$

and correlation between the left and right side at a given time point is

$$
r_{\text {right-left }}=\frac{\prod_{l} \sigma_{a l}+\sigma_{12}}{\prod_{l} \sqrt{\sigma_{a l}^{2}+\sigma_{l}^{2}+\sigma_{e}^{2}}},
$$

where $\sigma_{a l}^{2}$ is the animal variance for udder-half side $l$, $\rho$ is the autocorrelation parameter, $\sigma_{l}^{2}$ is the variance of the autoregressive process for side $l, \sigma_{12}$ is the residual covariance between left and right test-day SCS, and $\sigma_{e}^{2}$ is the measurement error variance. For newBAC and negBAC, correlation between test days $i$ and $j$ within an udder half $l$ can be written as

$$
r_{i j}=\frac{\sigma_{a}^{2}+\rho^{\left|t_{j}-t_{j}\right|} \sigma^{2}}{\sigma_{a}^{2}+\sigma^{2}},
$$

and the correlation between left and right side at a given time point is

$$
r_{\text {right-left }}=\frac{\sigma_{a}^{2}}{\sigma_{a}^{2}+\sigma^{2}},
$$

where $\sigma_{a}^{2}$ is the animal variance, $\rho$ is the autocorrelation parameter, and $\sigma^{2}$ is the variance of the autoregressive process.

\section{RESULTS}

\section{Descriptive Statistics}

From the survey of 78 ewes of both the Low and High SCS lines, with SCC records, including up to 9 record- 
Table 2. Descriptive statistics for the 2 divergent High and Low SCS lines (40 and 38 ewes, respectively)

\begin{tabular}{|c|c|c|c|c|}
\hline \multirow[b]{2}{*}{ Trait $^{1}$} & \multicolumn{2}{|c|}{ High SCS line } & \multicolumn{2}{|c|}{ Low SCS line } \\
\hline & Records, $\mathrm{n}$ & Mean (SD) & Records, $\mathrm{n}$ & Mean (SD) \\
\hline Test-day SCC, ${ }^{1} \times 10^{3}$ cells $/ \mathrm{mL}$ & 246 & $858(1,662)$ & 218 & $405(1,956)$ \\
\hline Test-day SCS ${ }^{1}$ & 246 & $4.48(2.14)$ & 218 & $2.90(1.70)$ \\
\hline Test-day SCSud ${ }^{2}$ & 495 & $3.96(2.29)$ & 460 & $2.20(1.55)$ \\
\hline Milk, ${ }^{3} \mathrm{~L} / \mathrm{d}$ & 246 & $0.88(0.41)$ & 218 & $0.90(0.4)$ \\
\hline Protein, g/L & 246 & $53.5(6.9)$ & 218 & $50.3(6.4)$ \\
\hline Fat, g/L & 246 & $64.4(13.6)$ & 218 & $63.1(13.0)$ \\
\hline $\mathrm{BAC}^{4^{\prime}}$ & 586 & $0.40(0.49)$ & 536 & $0.21(0.41)$ \\
\hline newBAC ${ }^{5}$ & 364 & $0.24(0.43)$ & 404 & $0.20(0.40)$ \\
\hline negBAC ${ }^{6}$ & 196 & $0.30(0.46)$ & 110 & $0.69(0.46)$ \\
\hline
\end{tabular}

${ }^{1}$ Results from composite milk of both half udders.

${ }^{2}$ Results from half-udder milk samples.

${ }^{3}$ Mean of morning milking volumes.

${ }^{4} \mathrm{BAC}=$ positive $(1)$ or negative $(0)$ bacteriological milk examination result.

${ }^{5}$ newBAC $=$ new bacteriological result: 1 for a positive BAC result, or 0 for a negative BAC result for udder halves with a negative BAC result $3 \mathrm{wk}$ before (previous sampling time point).

${ }^{6}$ negBAC $=$ bacteriological negativation: 1 for a negative BAC result, or 0 for a positive BAC result for udder halves with a positive BAC result 3 wk before (previous sampling time point).

ing time points throughout their first lactation, average test-day SCC and SCS (SD) were $645 \times 10^{3}$ cells $/ \mathrm{mL}$ $\left(1,819 \times 10^{3}\right.$ cells $\left./ \mathrm{mL}\right)$ and $3.74(2.10)$, respectively. On average, test-day SCS measured from half-udder milk samples was similar [i.e., 3.12 (2.15)]. Milk production was comparable in the 2 lines of ewes, whereas large differences in SCS were observed (Table 2). Differences in SCS between lines increased in the last months of lactation, essentially after the third month (after the beginning of pasture grazing; Figure 1).

During the entire first lactation of High and Low SCS line ewes $(\mathrm{n}=84)$, only 5 cases of CM were recorded. One case occurred at lambing, and the others developed approximately $15 \mathrm{~d}$ after lambing. Coagulase-negative staphylococci (Staphylococcus auricularis, Staphylococcus cohnii urealyticum, and Staphylococcus xylosus) were isolated from the 3 cases for which milk sampling had been possible (subacute cases). In the other 2 cases, peracute mastitis and sudden death precluded milk sampling.

On the other hand, systematic clinical evaluations of udders (4 times) performed in the milking parlor allowed us to record various signs of chronic mastitis. Abscesses and lacteal cysts were the most frequent (Table 3). The frequency of those chronic signs, especially abscesses, was significantly greater in the High than

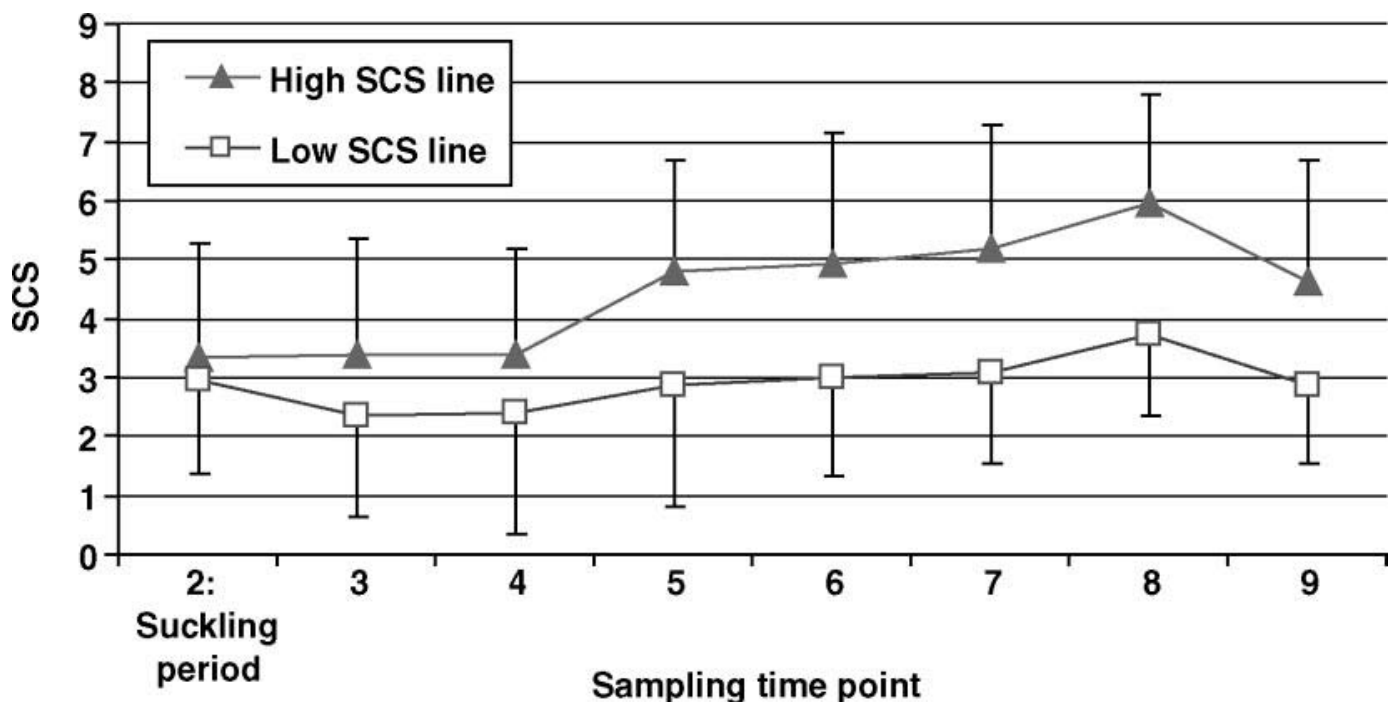

Figure 1. Average SCS $( \pm$ SD) by sampling time point during the first lactation of High SCS $(\boldsymbol{\Lambda})$ and Low SCS ( $\square)$ line ewes. 
Table 3. Results from mammary systematic clinical evaluations (4 times) of High and Low SCS line ewes

\begin{tabular}{|c|c|c|c|c|c|c|}
\hline Clinical symptom & \multicolumn{2}{|c|}{ Total (225 observations) } & \multicolumn{2}{|c|}{ High SCS line (117 observations) } & \multicolumn{2}{|c|}{ Low SCS line (108 observations) } \\
\hline Lacteal cysts & 28 & 12.4 & 24 & $21.1^{* * *}$ & 4 & $3.7^{* * *}$ \\
\hline Bacterial dermatitis & 7 & 3.1 & 5 & 4.3 & 2 & 1.9 \\
\hline Diffuse hardness & 4 & 1.8 & 2 & 1.7 & 2 & 1.9 \\
\hline
\end{tabular}

*** $P<0.001$ : significant difference in percentages between lines (Fisher's exact test).

in the Low SCS line. Furthermore, almost all abscess records ( $\mathrm{n}=19 / 22$, of 225 observations) were detected on udders with bacteriologically positive milk samples (at least for one udder half) concomitantly with the clinical evaluation. The presence of an abscess was not bacteria specific, because 7 different species were isolated from corresponding milk samples, with comparable repartitioning with organisms from the whole survey (Table 4). Conversely, only $18.6 \%$ of udders with positive milk samples had abscesses at the concomitant clinical evaluation.

Milk bacteriological examinations allowed us to define the etiology of mastitis. Of the 1,122 bacteriological results from healthy or nonacute mastitic animals, 350 were positive $(31.2 \%), 670$ were negative, and 102 were undetermined. The latter included paucibacterial cultures (fewer than 3 colonies per $100 \mu \mathrm{L}$ ) and contaminated samples (3 or more colony types). These results were associated with low $\operatorname{SCS}(2.55, \mathrm{SD}=1.88)$, in the same range as negative samples $(2.38, \mathrm{SD}=1.41)$, and were attributed to contamination during sampling. Accordingly, undetermined bacteriological results were grouped with negative results for further analyses. The $16 \mathrm{~S}$ rRNA sequencing allowed the speciation of the 56 incorrectly identified strains of staphylococci and streptococci. Of the 350 positive results, the most frequently isolated bacteria (Table 4) were staphylococci: Staph. auricularis (42.6\% of positive samples), Staphylococcus simulans, Staphylococcus haemoliticus, Staph. xylosus, Staphylococcus chromogenes, Staphylococcus lentus, Staphylococcus warneri, Staph. aureus, and Staphylococcus arlettae. The major pathogens and Staph. aureus accounted for 4.8 and $2.8 \%$ of positive samples, respectively. As reported in Table 2, the BAC rate was greater in the High SCS line $(40 \%)$ than in the Low SCS line (21\%). The repartitioning of bacterial species was comparable between lines in positive samples (Table 4): for the most frequently isolated bacteria, the frequency was significantly greater in the High SCS line than in the Low SCS line (Table 4). The average in-

Table 4. Milk bacteriological results in the 2 divergent High and Low SCS lines ${ }^{1}$

\begin{tabular}{|c|c|c|c|c|c|c|}
\hline \multirow[b]{2}{*}{ Bacteria identification } & \multicolumn{2}{|c|}{ Total } & \multicolumn{2}{|c|}{ High SCS line } & \multicolumn{2}{|c|}{ Low SCS line } \\
\hline & $\mathrm{n}$ & $\%$ & $\mathrm{n}$ & $\%$ & $\mathrm{n}$ & $\%$ \\
\hline Negative $^{2}$ & 772 & 68.8 & 351 & $59.9^{* * *}$ & 421 & $78.5^{* * *}$ \\
\hline Staphylococcus auricularis & 149 & 13.3 & 122 & $20.8^{* * *}$ & 27 & $5.0^{* * *}$ \\
\hline Staphylococcus simulans & 29 & 2.6 & 28 & $4.8^{* * *}$ & 1 & $0.2^{* * *}$ \\
\hline Staphylococcus haemoliticus & 28 & 2.5 & 9 & 1.5 & 19 & 3.5 \\
\hline Staphylococcus xylosus & 21 & 1.9 & 16 & $2.7^{*}$ & 5 & $0.9^{*}$ \\
\hline Staphylococcus chromogenes & 19 & 1.7 & 14 & $2.4^{*}$ & 5 & $0.9^{*}$ \\
\hline Staphylococcus lentus & 18 & 1.6 & 7 & 1.2 & 11 & 2.1 \\
\hline Staphylococcus warneri & 14 & 1.2 & 4 & 0.7 & 10 & 1.9 \\
\hline Staphylococcus aureus & 10 & 0.9 & 7 & 1.2 & 3 & 0.6 \\
\hline Staphylococcus arlettae & 10 & 0.9 & 4 & 0.7 & 6 & 1.1 \\
\hline Staphylococcus capitis & 8 & 0.7 & 5 & 0.9 & 3 & 0.6 \\
\hline Staphylococcus kloosii & 8 & 0.7 & 4 & 0.7 & 4 & 0.7 \\
\hline Staphylococcus equorum & 5 & 0.4 & 1 & 0.2 & 4 & 0.7 \\
\hline Staphylococcus epidermidis & 4 & 0.4 & 2 & 0.3 & 2 & 0.4 \\
\hline Other staphylococci ${ }^{3}$ & 12 & 1.1 & 8 & 1.4 & 4 & 0.7 \\
\hline Others $^{4}$ & 15 & 1.3 & 4 & 0.7 & 11 & 2.1 \\
\hline Total & 1,122 & 100.0 & 586 & 100.0 & 536 & 100.0 \\
\hline
\end{tabular}

${ }^{1}$ Nine sampling time points per udder half during the first lactation.

${ }^{2}$ Negative + contaminated bacteriological results.

${ }^{3}$ Less than 4 isolates of CNS.

${ }^{4}$ Less than 4 isolates: Corynebacterium spp., Enterococcus faecalis, Escherichia coli, Streptococcus spp.

${ }^{*} P<0.05,{ }^{* * *} P<0.001$ : significant difference in percentages between lines (Fisher's exact test). 
stantaneous infection rate was $25.3 \%$ at lambing (first sampling time point); was the lowest at sampling time points 2 (suckling period) and 3, with 23.4 and $19.6 \%$ of positive samples, respectively; and was increased in the later stages of lactation (37.9\%, on average).

The rates of newBAC and negBAC were, respectively, 22.0 and $44.1 \%$, on average. Accordingly, more than one-half $(55.9 \%)$ of the positive samples were still positive at the next sampling time point ( 3 wk later): $41.2 \%$ with the same bacterial species and $14.7 \%$ with a different bacterial species. The BAC and newBAC rates were greater in the High SCS line than in the Low SCS line, whereas negBAC rates were greater in the Low SCS line compared with the High SCS line (Table 2).

Regarding the dynamics of infection, only 9 (7.5\%) of 120 half udders with a complete sampling scheme remained negative during the follow-up. Udder halves experienced $1.68( \pm 1.02)$ successive infections with different bacterial species, on average. Ewes from the High and Low SCS lines showed comparably low frequencies of persistently negative half udders (6 and 3, respectively) and showed a similar average number of infections (1.67 \pm 1.08 and $1.69 \pm 0.95$, respectively). On average, the durations of infection (mean number of successive positive samples for a given bacteria) were $2.32( \pm 2.37), 2.30( \pm 2.16), 1.75( \pm 2.3), 1.62( \pm 1.63), 1$, and 1 for the main bacterial species: Staph. auricularis, Staph. chromogenes, Staph. xylosus, Staph. haemoliticus, Staph. lentus, and Staph. warneri, respectively (data not shown). The durations of infection (Figure 2) were significantly greater in the High SCS line $(2.30 \pm$ $2.46)$ than in the Low SCS line $(1.21 \pm 0.88)$. Irrespective of bacterial species, the total duration of infections within udder halves was $4.24( \pm 2.80)$ and 2.17 $( \pm 1.41)$ in the High and Low SCS lines, respectively, for approximately 50 and $25 \%$ of the survey period (Figure 2). First infections (data not shown) occurred essentially at lambing $(28.8 \%)$ or just after the suckling period (27\%). Staphylococcus auricularis was the main bacterial species responsible for first infections (34 and $62 \%$ for the Low and High SCS lines, respectively), similar to the whole-survey results. The other bacteria belonged to CNS for both lines, with similar species profiles. Staphylococcus aureus was associated with 2 infections in both lines. The duration of the first infection within udder halves was comparable in the High and Low SCS lines whenever it started. First infections occurred earlier, on average, in the High SCS line than in the Low SCS line [e.g., at time points $3.24( \pm 2.34)$ and $4.45( \pm 2.27)$, respectively]. A low proportion of infections occurred at lambing in the Low SCS line (15.1\%) compared with the High SCS line (41.4\%).

\section{Difference Between Lines for SCS and Milk Production Traits}

Analysis of variance indicated a significant effect $(P$ $\leq 0.05$ ) of line and time point on SCS. The estimated SCS $( \pm$ SE) were $4.46( \pm 0.25)$ and $2.77( \pm 0.19)$ in the High and Low SCS lines, respectively. This difference between lines (1.69) increased to 1.85 units of SCS when the first SCS measure during the suckling period was not considered (data not shown). The time point had a significant effect on SCS, with the lowest estimated values $(2.86 \pm 0.27)$ in early lactation (sampling time point 3) and a regular increase in SCS with DIM, as illustrated by the evolution of raw SCS in the 2 lines during the first lactation (Figure 1). The correlation between successive SCS records within an animal (at 3 -wk intervals) was high (0.59; Table 5).

Milk yield and fat content did not differ significantly between lines. Protein content, however, was significantly greater in the High SCS line $(51.7 \pm 5.8 \mathrm{~g} / \mathrm{L})$ than in the Low SCS line $(48.3 \pm 8.1 \mathrm{~g} / \mathrm{L})$, with a moderate estimated difference of $3.4 \mathrm{~g} / \mathrm{L}$ between lines.

\section{Difference Between Lines for Milk Bacterial Isolations}

Table 5 shows covariance parameters in models for bacteriological examination traits, and correlation coefficients between repeated measurements within animal. Correlations between successive measurements (at 3-wk intervals) were moderate for $\mathrm{BAC}$ and newBAC (0.40 to 0.48 ) and high for negBAC (0.73). Correlations between measures on milk samples from the left and right udder halves were low for newBAC (0.11), intermediate for BAC (0.35), and high for negBAC (0.60).

Analysis of variance results for milk bacteriology traits (BAC, newBAC, and negBAC) are summarized in Table 6. Milk samples from High SCS line ewes had a 3 -times greater chance [odds ratio $(\mathbf{O R})=3.1$ (1.9; 5.2)] of being positive (BAC) than milk samples from Low SCS line ewes. The estimated probability of positive samples (BAC) was the lowest (13 to 19\%) during the suckling period and early after weaning (sample time point 3), and was increased in late lactation to $37 \%$.

The newBAC rate was significantly greater at lambing only in the High SCS line compared with the Low SCS line (Figure 3). Indeed, the significant interaction term between time point and line effects on newBAC indicated that milk samples collected shortly after lambing had a 4.5-times greater chance $[\mathrm{OR}=4.5(1.9$; 8.4)] of being positive in High SCS line ewes than in Low SCS line ewes (data not shown). The newBAC rate 


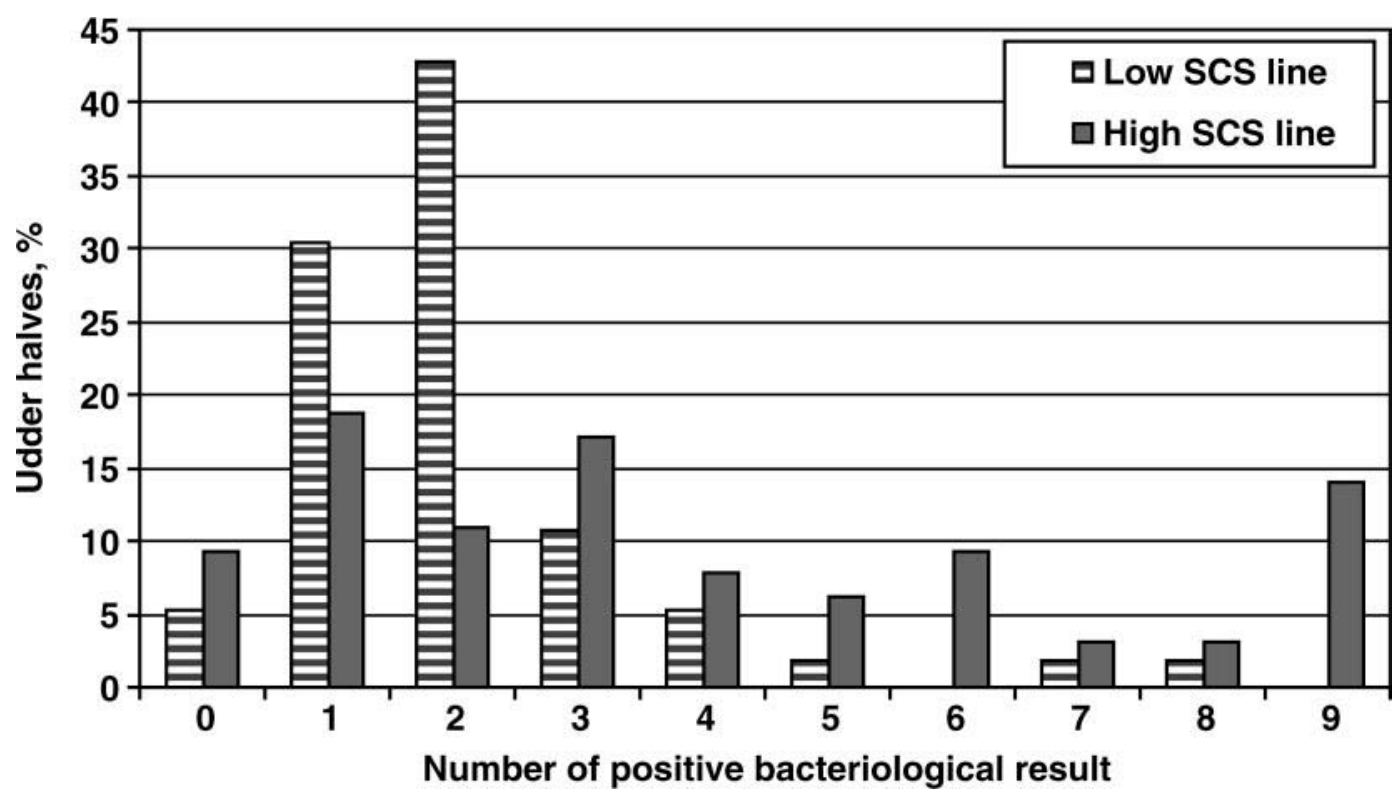

Figure 2. Total duration of infections (number of successive positive samples for a given bacterium) within udder halves according to the SCS line (total number of udder halves $=120$ ).

was similar in both lines from the midsuckling period (sampling time point 2) to the end of lactation.

The negBAC rate was 5 times lower in the High SCS line than in the Low SCS line $[\mathrm{OR}=0.2(0.1 ; 0.6)]$. The significant interaction term between time point and line further indicated that this difference was stable during the entire exclusive milking period (sampling time points 3 to 9 ), whereas no difference in the negBAC rate was observed during the suckling period (Figure $4)$.

\section{Line and Milk Bacteriology Effects on Half-Udder SCS}

Correlations (Table 5) between successive SCSuh measurements (at 3-wk intervals) within animal and

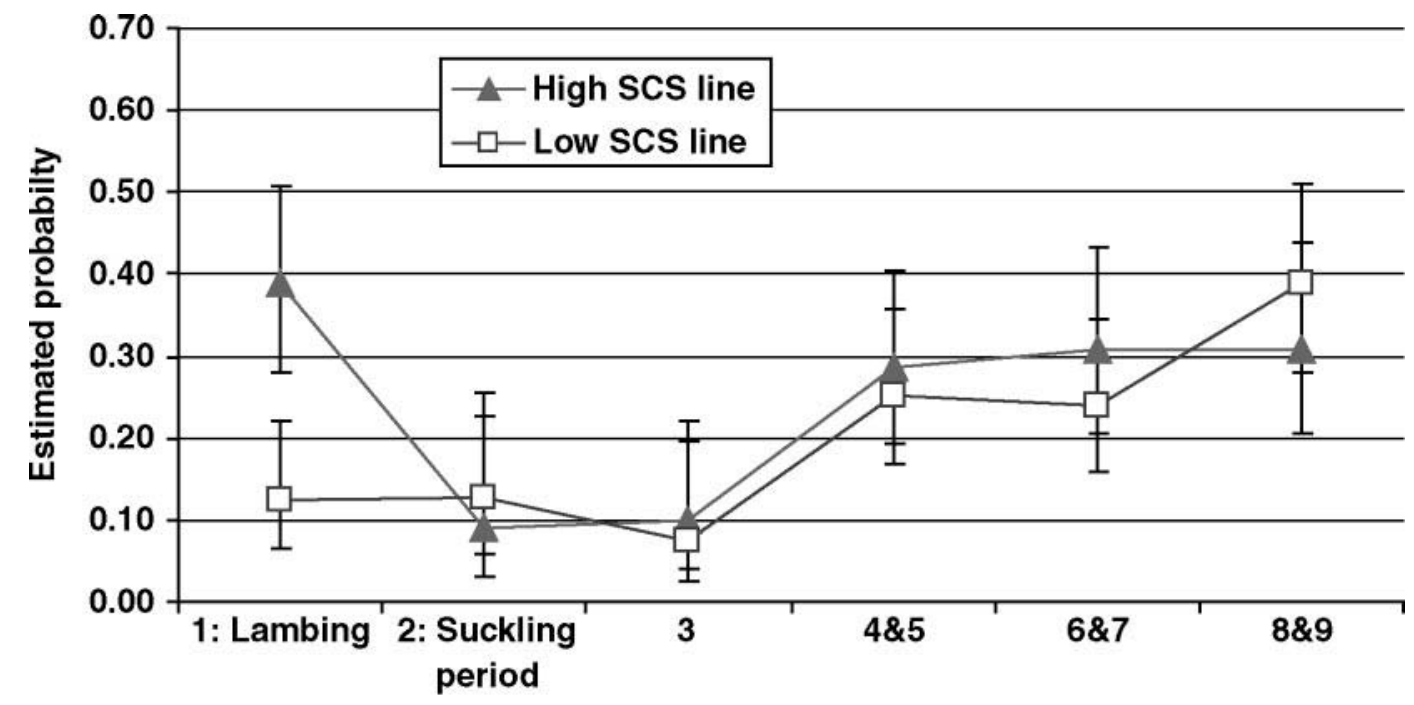

Sampling time point

Figure 3. Estimated probabilities $( \pm 2 \mathrm{SE})$ from generalized mixed logistic models for newBAC in the High SCS $(\boldsymbol{\Lambda})$ and Low SCS $(\square)$ lines, according to sampling time point. NewBAC $=1$ if a positive bacteriological milk examination result (BAC), given that the previous result on the same half udder was negative, or 0 otherwise. 
Table 5. Covariance parameters for the $\mathbf{G}\left(\sigma_{a}^{2}\right)$ and $\mathbf{R}\left(\rho, \sigma^{2}, \sigma_{e}^{2}\right)$ matrices in the final models for test-day SCS and bacteriological examination traits

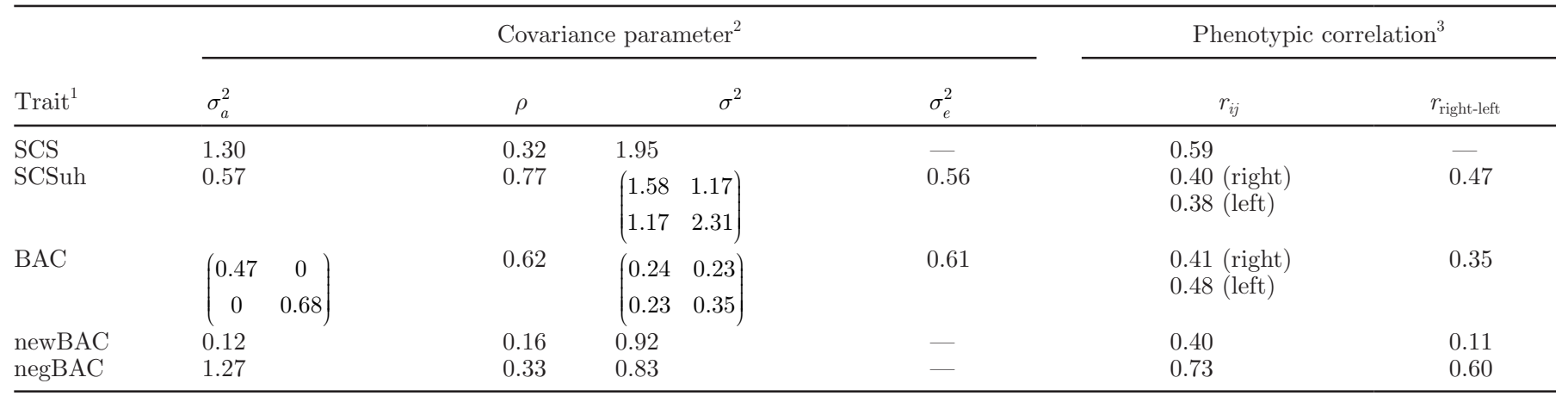

${ }^{1} \mathrm{SCS}=$ test-day SCS from composite milk samples; SCSuh = test-day SCS from udder-half milk samples; BAC = bacteriological milk examination result (positive vs negative); newBAC $=$ new bacteriologically positive result; negBAC $=$ negativation from a positive bacteriological result.

${ }^{2} \sigma_{a}^{2}=$ animal variance; $\rho=$ autocorrelation parameter; $\sigma^{2}=$ variance of the autoregressive process; $\sigma_{e}^{2}=$ measurement error variance.

${ }^{3} r_{i j}=$ correlation between successive test-day measures (3-wk interval) for a given subject (animal or udder half); $r_{\text {right-left }}=$ correlation between measures from right and left udder-half milk samples at a given time point. See formulae in the text.

between the left and right udder-half results were moderate (0.40 to 0.47). Significant effects on SCSuh were the following: line $(+1.78$ SCS in the High vs. the Low SCS line), sampling time point (+1.31 at sampling point 9 compared with the suckling period), lambing week $(+0.85$ SCS for ewes lambing the first week of January compared with ewes lambing 1 wk later), and bacteriological status of the udder-half BAC $(+0.48$ SCS for positive compared with negative half-udder milk samples). Additionally, several interaction terms had a significant effect on SCSuh. First, the effect of bacteriological status was greater in the High $(+0.74$ SCS) than in the Low $(+0.21$ SCS $)$ SCS line. The effect of bacteriological status of the udder half on SCSuh was greater during the suckling period $(+1.00$ SCS $)$ than at other sampling time points ( +0.40 SCS on average). The difference in SCSuh between High and Low SCS line ewes was greater during the suckling period $(+2.27)$ than during sampling time points 3 to $9(+1.71$, on average). Finally, the significant interaction term between line, sampling time point, and BAC (Figure 5) indicated that, for positive milk samples, ewes from the High SCS line continually had greater SCS than ewes from the Low SCS line $(+2.04$ SCS, on average), with an especially large difference between lines during the suckling period $(+3.42$ SCS). The observed SCSuh of positive milk samples confirmed that trend for almost all of the 10 most frequently isolated bacterial species: Figure 6 shows exceptionally greater SCS in the Low SCS line for Staph. chromogenes, whereas SCS was greater in the High SCS line for other bacteria. The data size was small, however, and the results must be interpreted cautiously and require further evidence. For negative milk samples, differences between lines were moderate (i.e., an average difference of +1.52 in the High SCS line compared with the Low SCS line) and maximum at the end of lactation.

\section{DISCUSSION}

The average milk production and SCC results of the animals in this study were in the range of classical results for the INRA experimental flock and of contemporary data for French commercial Lacaune flocks. Individual test-day SCC and SCS recorded 2 to 3 times at the beginning of the first lactation of Lacaune ewes enrolled in the milk-recording scheme $(113,147$ records in 2005 , the contemporary campaign to the present study) were, on average, $374 \times 10^{3}$ cells $/ \mathrm{mL}\left(\mathrm{SD}=1,252 \times 10^{3}\right)$ and $3.02(\mathrm{SD}=1.74)$, respectively. Comparative data from our experiment (records from 25 to $145 \mathrm{~d}$ postpartum) were $545 \times 10^{3}$ cells $/ \mathrm{mL}\left(\mathrm{SD}=1,307 \times 10^{3}\right)$ and 3.60 $(\mathrm{SD}=2.08)$, respectively. Regarding mastitis, 2 reviews (Contreras et al., 1995; Bergonier et al., 2003), based on large-scale surveys, reported similar CM frequencies (less than $5 \%$, on average) as well as clinical or subclinical IMI etiologies similar to those reported for the experimental Low and High SCS line ewes. In both reviews, the authors reported the definite predominance of CNS (60 to $90 \%$ of bacteriologically positive milk samples) as causal agents of subclinical (to chronic) mastitis, with Staph. epidermidis and Staph. chromogenes (also identified in our study) being among the most frequently isolated species on farm. Bergonier et al. (2003) also reported a high prevalence of Staph. xylosus and Staph. simulans. Regarding CM in dairy 
sheep, the same reviews reported that coagulase-positive staphylococci and CNS, on average, accounted for 65 to $85 \%$ of cases (peracute forms mainly originating from coagulase-positive staphylococci). In the present bacteriological records, 3 mild clinical cases were due to CNS, and the 2 others were peracute forms with immediate death (no milk sampling performed). According to the clinical descriptions in the literature and the 15yr bacteriological systematic mastitis survey performed by our group in this experimental flock (Bergonier et al., 2005), the peracute clinical cases are likely to be due to Staph. aureus. Finally, the typical symptoms of chronic CM in the dairy ewe are, in decreasing order of frequency, unbalanced udders, abscesses, and parenchymal diffuse hardness (Ziluaga et al., 1998; Bergonier et al., 2005). The clinical, epidemiological, and etiological situation of the experimental High and Low SCS flocks was therefore comparable to that of commercial sheep flocks in the same area.

The ovine species was chosen as a model for studying ruminant mastitis because of 1 ) the better feasibility of producing, raising, and monitoring a significant number of animals; 2) the availability of SCC recording and genetic evaluation on a large sheep population; and 3) strong similarities in the physiopathology of mastitis with dairy cattle. Although this experiment was developed in dairy sheep, the results may be partly transposed to dairy cattle. On one hand, the etiology of dairy cow subclinical mastitis is close to that of the dairy ewe. The most prevalent causative organisms are staphylococci, followed by streptococci and corynebacteria; gram-positive organisms thus represent 70 to $90 \%$ of isolates in both host species (Contreras et al., 1995; Bergonier et al., 2003; Bradley et al., 2007; Piepers et al., 2007). Moreover, the most frequent subclinical mastitis-causing organisms in primiparous females, for both cows and ewes, in the peripartum and beginning lactation periods are CNS. Because the duration of these frequent bacteriologically positive results is often short around parturition, they may be considered either as brief mammary cisternal infections, teat colonization without a full associated inflammatory reaction, or simple duct contaminations (Daniel et al., 1986; Bergonier and Berthelot, 2003; Parker et al., 2007). In addition, the SCC means in both species are very similar. In bacteriologically negative udders, composite milk SCC ranges from 50 to $250 \times 10^{3}$ cells $/ \mathrm{mL}$ in most cattle and sheep studies, and the same physiological thresholds have been proposed (200 to $300 \times 10^{3}$ cells/ $\mathrm{mL}$; Djabri et al., 2002; Berthelot et al., 2006). The same kind of SCC biological significance is described in the cow and ewe, whereas in the goat several differences do exist (apocrine milk secretion, cellular subpopulation peculiarities, importance of nonbacterial variation

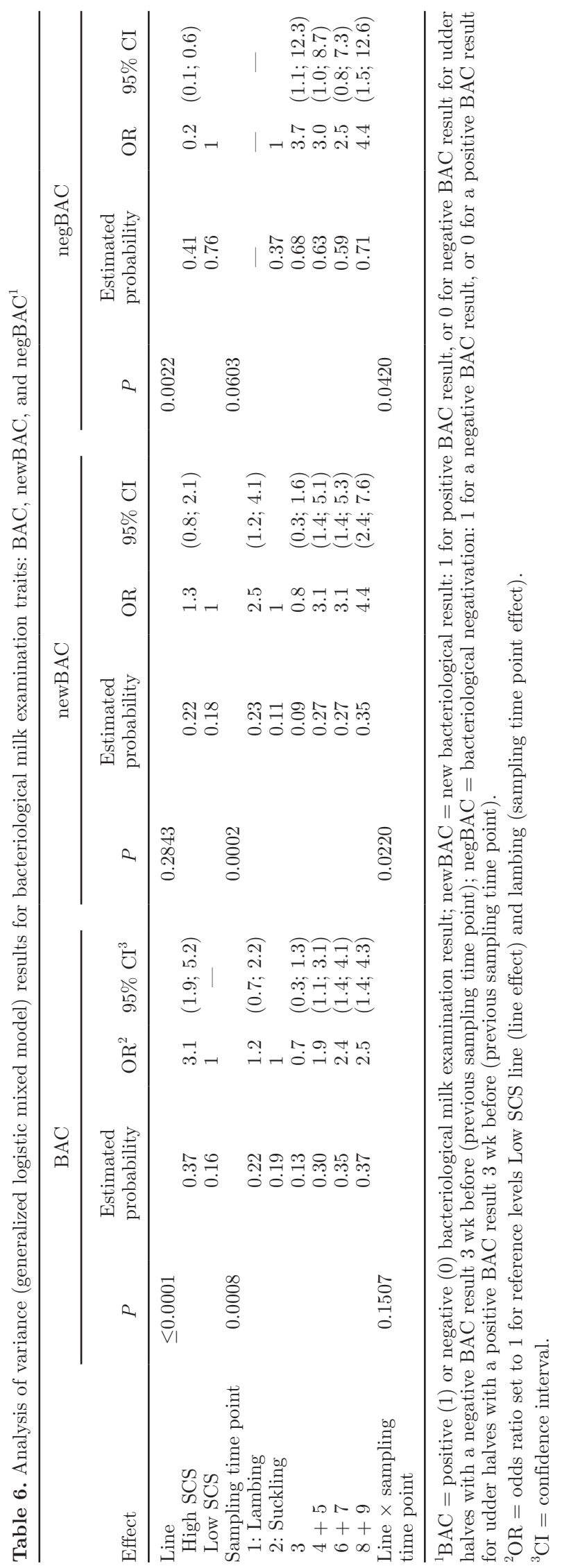




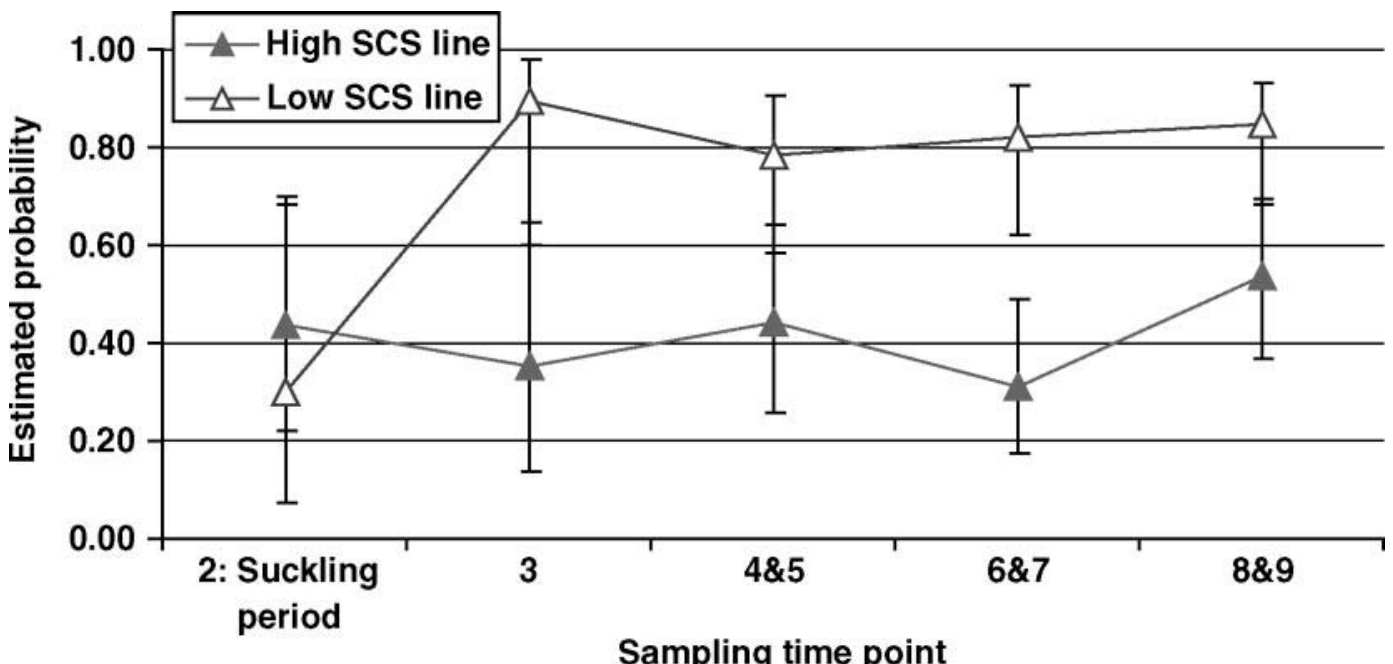

Figure 4. Estimated probabilities $( \pm 2 \mathrm{SE})$ from generalized mixed logistic models for negBAC in the High SCS $(\boldsymbol{\Delta})$ and Low SCS $(\square)$ lines, according to sampling time point. NegBAC $=1$ if negative bacteriological milk examination result (BAC), given that the previous result on the same half udder was positive, or 0 otherwise.

factors, etc.; Paape et al., 2001; Bergonier et al., 2003). Additionally, genetic parameters of SCS in the French Lacaune dairy sheep breed (Rupp et al., 2003) indicated a heritability of 0.13 and a moderate and unfavorable correlation between SCS and milk production traits. The results were close to the cattle estimates reviewed earlier (Mrode and Swanson, 1996; Rupp and Boichard, 2003), indicating a similar extent of genetic control of the trait in both species.

The experimental design allowed for a large difference, 1.69 units of SCS [i.e., 3.2 genetic SD $\left(\boldsymbol{\sigma}_{\mathrm{g}}\right)$ ], to be created between the High and Low SCS lines, based on sire and dam SCS EBV selection. From 2007 onward, SCS (a lactation mean of 2 to 3 test-day SCS) is included in the selection index of the Lacaune dairy sheep breed, in addition to production and udder traits, to improve resistance to mastitis (Barillet et al., 2007). Following Barillet et al. (2007), breeders have chosen to put the same relative weight on functional traits (SCS and udder traits) and production in the total merit index. Accordingly, the genetic change expected on SCS is close to $1 \sigma_{\mathrm{g}}$ in $10 \mathrm{yr}$. The difference between the High

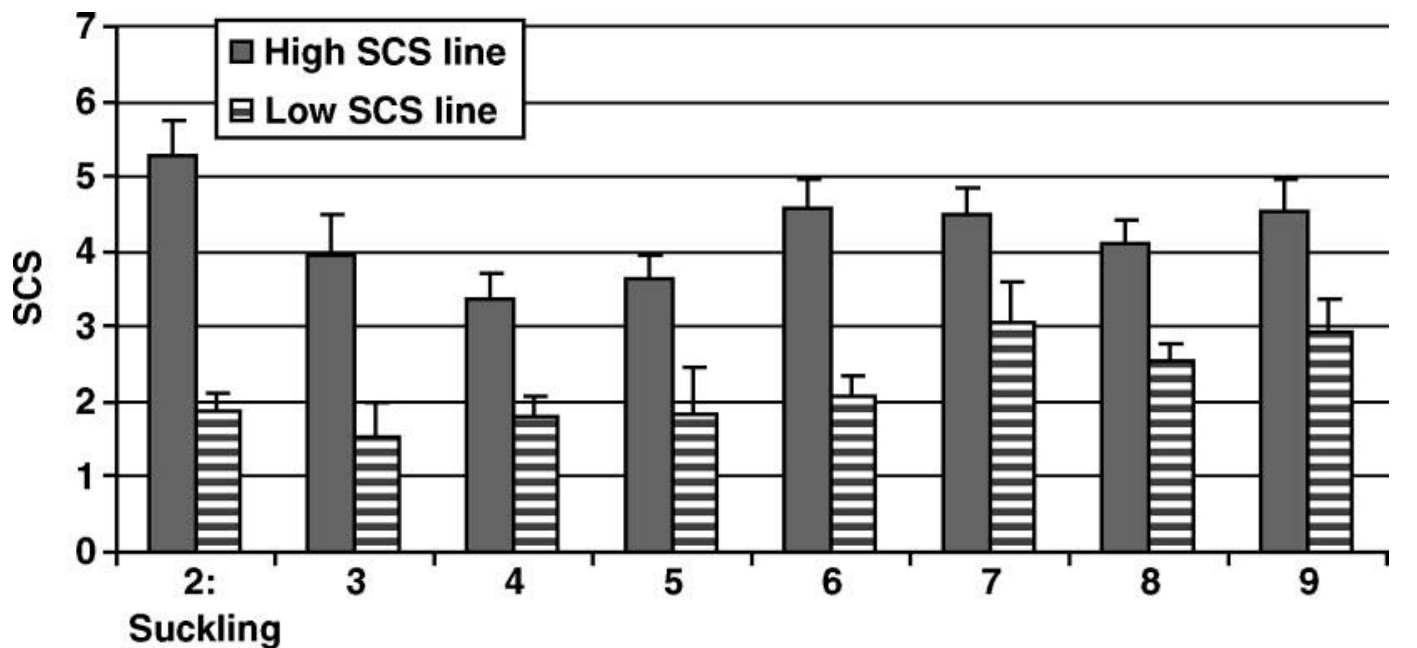

period

period

Sampling time point

Figure 5. Estimated half-udder SCS (least squares means \pm SE) for bacteriologically positive milk samples in the High SCS and Low SCS lines according to sampling time point [Line $\times$ sampling time point $\times$ bacteriological milk examination result (BAC) interaction effect]. 


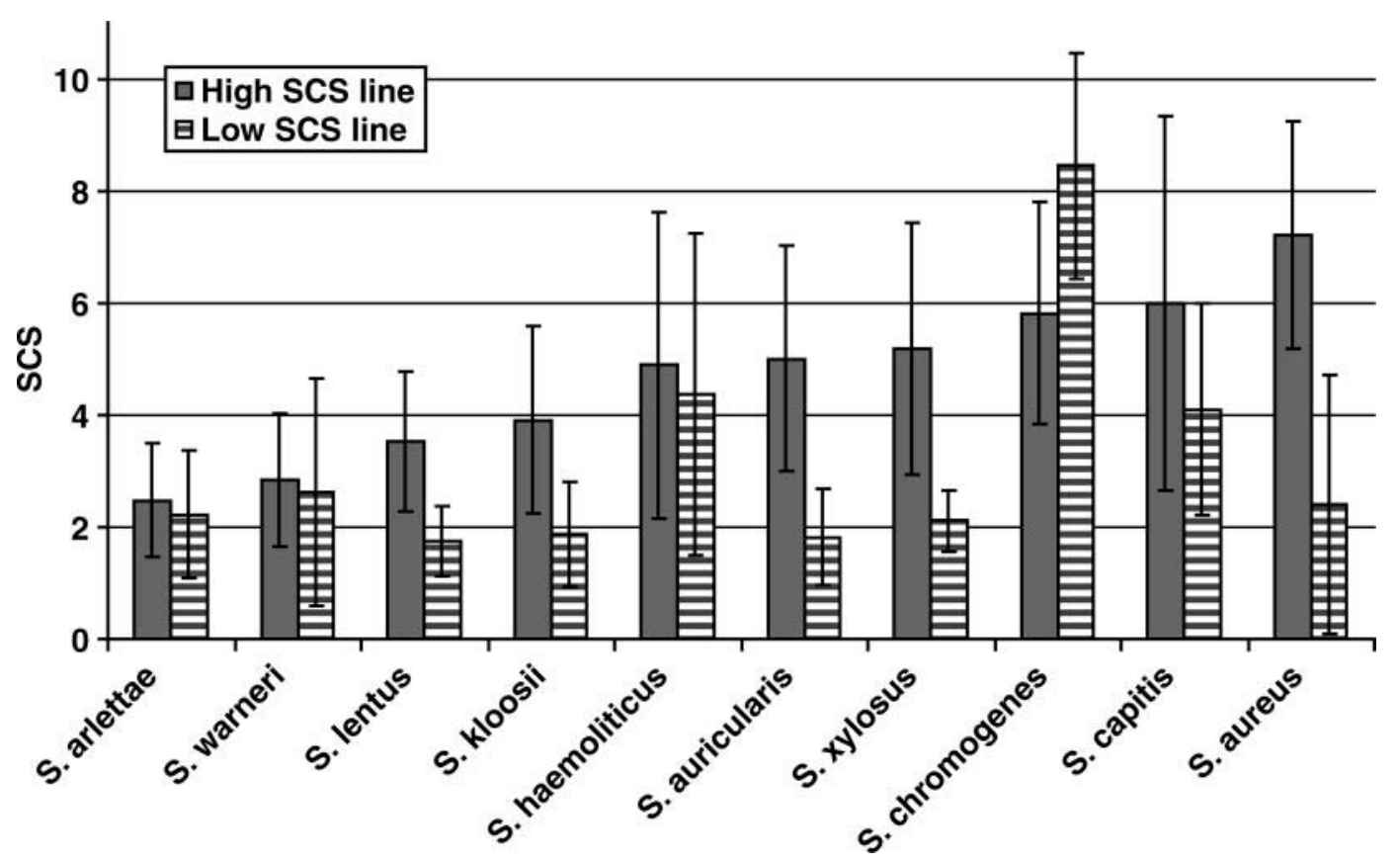

Figure 6. Average half-udder SCS $( \pm \mathrm{SD})$ for bacteriologically positive milk samples in the High SCS and Low SCS lines according to isolated bacterial species (Staphylococcus spp.). Data for the main bacterial species only (i.e., at least 3 isolates per line with SCS information).

and Low SCS lines therefore mimics approximately 30 yr of selection. Observations on the divergent selection reported here therefore add some information on the likely long-term effects and efficacy of SCS-based selection on farm regarding IMI, with the limitation of the small size of the experimental design.

The survey of first-lactation ewes from the High and Low SCS lines suggested favorable responses to SCS-based selection on the resistance to natural IMI. First, results suggested that Low SCS line ewes were not at greater risk of CM compared with High SCS line ewes. Indeed, although they were scarce, all clinical cases occurred in the High SCS line. Additionally, the incidence of chronic CM, as detected by the systematic clinical evaluations of udders, was much greater in the High SCS line than in the Low SCS line. The animals with abscesses were mostly ewes with long-lasting IMI, as evidenced by milk bacteriological examinations. The presence of parenchymal abscesses is a typical ante- and postmortem clinical observation for ruminant mastitis because of gram-positive cocci, and particularly staphylococci (Schalm et al., 1971). Results were therefore in agreement with the favorable genetic correlations between SCS and CM reported earlier in cattle (Heringstad et al., 2003b; Rupp and Boichard, 2003) and the absence of signs of nonlinearity of the latter correlation. Additionally, results from this study correlated well with a previous study indicating that Low SCS cows were at the lowest risk of CM (Rupp et al., 2000).
The comprehensive milk sampling and bacteriological protocol allowed for a detailed analysis of IMI in both lines. The average incidence of positive samples of $31.2 \%$ over 9 sampling time points resulted in only a very low proportion of consistently negative udder halves. To increase the rate of detection, samples that gave negative results after a 1-d culture were submitted to enrichment in brain-heart infusion broth and subsequent plating onto trypticase soy agar. Moreover, all plates were incubated in a normal atmosphere and then in a $\mathrm{CO}_{2}$-enriched atmosphere. This procedure allowed for a better culture of certain bacterial species, including CNS and Corynebacterium spp., which may be very prevalent in ewe mastitis (Bergonier and Berthelot, 2003). Part of the positive samples, however, may be interpreted as transitory infections or colonization of the teat rather than as an established udder infection. On the contrary, negative milk samples in previously and subsequently positive half udders may reflect intermittent shedding of bacteria (transitory eclipse). Because the latter facts could not be unraveled in the present study, and to simplify terminology, all positive bacteriological results were considered for our definition of mammary infections. To estimate the duration of infections, negative results were considered from uninfected udders only when they were different from cases of intermittent shedding. Therefore, consideration of the dynamics of infections (number, duration, lactation stage), based on precise identification of bacterial spe- 
cies and characterization of strain biochemical profiles, was useful to compare the mammary infection status of both lines.

The analysis of positive BAC results showed a significantly greater IMI prevalence in High SCS than in Low SCS animals $(\mathrm{OR}=3.1)$, which was constant over the survey period (i.e., from lambing to approximately 6 mo of lactation). Prevalence is a result of the incidence and duration of infections. The analyses of the dynamics of infection on repeated samplings for each udder half with detailed identification of pathogens allowed both components to be disentangled. On the contrary, the rate of new instantaneous positive results, or incidence, was greater in the High SCS line (39\%) than in the Low SCS line (12\%) at lambing (Figure 3 ), indicating that High SCS line ewes were especially susceptible to postpartum subclinical mastitis. Given the great persistency of postpartum positive results at the following sampling time points, these results may reflect, in large part, established IMI rather than transitory teat canal colonization. After the peripartum period, however, similar rates of new positive results for both lines seemed to indicate a comparable ability to avoid penetration of pathogens into negative mammary glands during lactation. Negativation was, however, markedly different between lines after weaning (41 and $84 \%$ in the High and Low SCS lines, respectively). This result was consistent with differences in the duration of infection, which were much greater in the High SCS line compared with the Low SCS line. Together with the high repeatability of the negBAC rate between udder halves of an animal, the results seemed to indicate that there is a strong individual component in the ability to avoid a durable establishment of infections.

Interestingly enough, part of the differences in susceptibility between the Low and High SCS lines seemed to be emphasized at the peripartum period: positive bacteriology and clinical case rates, and average SCS in positive samples. The results correlated well with literature data on the increased susceptibility of the mammary gland during the peripartum period (Oliver and Sordillo, 1988; Burvenich et al., 2007) and with genetic control of several immunological parameters around parturition (Detilleux et al., 1994; Kelm et al., 1997) in dairy cattle. Indeed, accumulating evidence supports the hypothesis of postpartum immunosuppression, leading to an increased incidence and severity of infectious diseases during early lactation, although causal phenomena and underlying modifications to the immune system are far from being fully understood. Of the different components of the peripartum mammary immune response, neutrophil functionality is of particular interest because it shows large genetic variability $\left(\mathrm{h}^{2}\right.$ $>0.70$ ) (Detilleux et al., 1994) and an opposite correla- tion (up to $-0.26, P \leq 0.05$ ) with EBV for SCS (Kelm et al., 1997). Although difficult to interpret (few data, variable estimates), the correlation of the EBV for CM and IMI with the EBV for immune trait suggested that neutrophils with greater inherent mobility were associated with less CM and IMI (Kelm et al., 1997).

Altogether, the difference in milk SCS means between the High and Low SCS lines was due to differences in IMI incidence and duration, and in SCS levels in infected half udders (even for given bacterial species). Because different bacterial pathogens may elicit different types of inflammatory responses, the difference between lines may have been related to the difference in the proportions of different bacterial species. However, the repartitioning of bacterial species in positive samples was quite comparable between lines. Furthermore, the SCS in positive samples was consistently lower in the Low SCS line than in the High SCS line for a given bacteria. The fact that Low SCS line ewes showed consistently lower SCS in positive milk samples than High SCS line ewes may suggest that fewer bacteria had entered the mammary gland, involving better first-line defense mechanisms in the teat canal, or that some defense mechanisms were more rapid and efficient, limiting the multiplication of bacteria or the inflammation process, or both. Disentangling the different components requires further investigation (bacteria quantification, survey of immune parameters during the early stages of infections, etc.). Overall, results from the current study suggest that the better resistance of Low SCS line ewes, compared with High SCS line ewes, is principally characterized by a better ability to 1 ) limit IMI during the peripartum period; 2) to eliminate IMI during lactation; and 3) quantitatively to limit the inflammation process (and its clinical consequences). Those differences might prefigure long-term responses to SCS-based selection.

\section{CONCLUSIONS}

Using dams and progeny-tested rams selected for extreme EBV for SCS, we created 2 groups of ewes, the High and Low SCS lines, with a strong divergence in SCS of approximately $3 \sigma_{\mathrm{g}}$. Preliminary results from a first-lactation survey provided evidence that EBV SCSbased selection may help improve resistance to clinical and subclinical mastitis: Low SCS line animals showed a lower incidence of CM; a lower prevalence of mammary abscesses and subclinical IMI, especially at parturition; a better ability to recover from IMI contracted during lactation; and lower SCS in bacteriologically positive samples. Additional analyses of the present cohort and a new one (duplicated design in 2005) and further data collection are in progress. The present design should 
allow for further investigations of host mechanisms leading to improved resistance to IMI by gram-positive bacteria.

\section{ACKNOWLEDGMENTS}

The authors acknowledge the staff of the INRA experimental unit La Fage, and especially Fabien Carriere, Jean-Marie Menras, Francois Pailler, and David Portes for technical support in producing, raising, and monitoring the animals. We thank Claudie Offer for technical assistance at the sequencing platform of IFR30, Toulouse Genopole. This work was supported by grants from the Midi-Pyrenees Region, GENANIMAL 2003, and ACI microbiologie 2003 projects.

\section{REFERENCES}

Ali, A. K. A., and G. E. Shook. 1980. An optimum transformation for somatic cell concentration in milk. J. Dairy Sci. 63:487-490.

Altschul, S. F., T. L. Madden, A. Schäffer, J. Zhang, Z. Zhang, W. Miller, and D. J. Lipman. 1997. Gapped BLAST and PSI-BLAST: A new generation of protein database search programs. Nucleic Acids Res. 25:3389-3402.

Barillet, F., J. M. Astruc, and G. Lagriffoul. 2007. Taking into Account Functional Traits in Dairy Sheep Breeding Programs Through the French Example. Eur. Assoc. Anim. Prod., Kuopio, Finland.

Bergonier, D., and X. Berthelot. 2003. New advances in epizootiology and control of ewe mastitis. Livest. Prod. Sci. 79:1-16.

Bergonier, D., R. de Crémoux, R. Rupp, G. Lagriffoul, and X. Berthelot. 2003. Mastitis of dairy small ruminants. Vet. Res. 34:689-716.

Bergonier, D., G. Lagriffoul, F. Barillet, R. Rupp, A. Valognes, R. Brugidoux, R. Duquesnel, and X. Berthelot. 2005. Aetiological, clinical and epidemiological characterization of clinical mastitis in dairy sheep. Pages 497-503 in Mastitis in Dairy Production: Current Knowledge and Future Solutions. H. Hogeveen, ed. Wageningen Academic Publisher, Wageningen, the Netherlands.

Berthelot, X., G. Lagriffoul, D. Concordet, F. Barillet, and D. Bergonier. 2006. Physiological and pathological thresholds of somatic cell counts in ewe milk. Small Rumin. Res. 62:27-31.

Bradley, A. J., K. A. Leach, J. E. Breen, L. E. Green, and M. J. Green. 2007. Survey of the incidence and aetiology of mastitis on dairy farms in England and Wales. Vet. Rec. 160:253-257.

Burvenich, C., D. D. Bannerman, J. D. Lippolis, L. Peelman, B. J. Nonnecke, M. E. Kehrli Jr., and M. J. Paape. 2007. Cumulative physiological events influence the inflammatory response of the bovine udder to Escherichia coli infections during the transition period. J. Dairy Sci. 90 (E Suppl.):E39-E54.

Carlén, E., E. Strandberg, and A. Roth. 2004. Genetic parameters for clinical mastitis, somatic cell score, and production in the first three lactations of Swedish Holstein cows. J. Dairy Sci. 87:30623070.

Contreras, A., J. C. Corrales, D. Sierra, and J. Marco. 1995. Prevalence and aetiology of non-clinical intramammary infection in MurcianoGranadina goats. Small Rumin. Res. 17:71-78.

Cranford, J. L., and R. E. Pearson. 2001. Relationships of sire predicted transmitting ability for somatic cell score with measures of daughter performance. J. Dairy Sci. 84:1501-1507.

Daniel, R. C., D. A. Barnum, and K. E. Leslie. 1986. Observations on intramammary infections in first calf heifers in early lactation. Can. Vet. J. 27:112-115.

Detilleux, J. C., K. J. Koehler, A. E. Freeman, M. E. Kehrli Jr., and D. H. Kelley. 1994. Immunological parameters of periparturient Holstein cattle: Genetic variation. J. Dairy Sci. 77:2640-2650.
Djabri, B., N. Bareille, F. Beaudeau, and H. Seegers. 2002. Quarter milk somatic cell count in infected dairy cows: A meta-analysis. Vet. Res. 33:335-357.

Emanuelson, U., B. Danell, and J. Philipsson. 1988. Genetic parameters for clinical mastitis, somatic cell counts, and milk production estimated by multiple-trait restricted maximum likelihood. J. Dairy Sci. 71:467-476.

Godon, J. J., E. Zumstein, P. Dabert, F. Habouzit, and R. Moletta. 1997. Molecular microbial diversity of an anaerobic digestor as determined by small-subunit rDNA sequence analysis. Appl. Environ. Microbiol. 63:2802-2813.

Heringstad, B., D. Gianola, Y. M. Chang, J. Odegård, and G. Klemetsdal. 2006. Genetic associations between clinical mastitis and somatic cell score in early first-lactation cows. J. Dairy Sci. $89: 2236-2244$.

Heringstad, B., G. Klemetsdal, and J. Ruane. 2000. Selection for mastitis in dairy cattle: A review with focus on the situation of the Nordic countries. Livest. Prod. Sci. 64:95-106.

Heringstad, B., G. Klemetsdal, and T. Steine. 2003a. Selection responses for clinical mastitis and protein yield in two Norwegian dairy cattle selection experiments. J. Dairy Sci. 86:2990-2999.

Heringstad, B., G. Klemetsdal, and T. Steine. 2007. Selection responses for disease resistance in two selection experiments with Norwegian Red cows. J. Dairy Sci. 90:2419-2426.

Heringstad, B., R. Rekaya, D. Glanola, G. Klemetsdal, and K. A. Welgel. 2003b. Genetic change for clinical mastitis in Norwegian cattle: A threshold model analysis. J. Dairy Sci. 86:369-375.

International Dairy Federation. 1981. Laboratory Methods for Use in Mastitis Work. Doc. 132. Int. Dairy Fed., Brussels, Belgium.

Kelm, S. C., J. C. Detilleux, A. E. Freeman, M. E. Kehrli Jr., A. B. Dietz, L. K. Fox, J. E. Butler, I. Kasckovics, and D. H. Kelley. 1997. Genetic association between parameters of inmate immunity and measures of mastitis in periparturient Holstein cattle. J. Dairy Sci. 80:1767-1775.

Koivula, M., E. A. Mäntysaari, E. Negussie, and T. Serenius. 2005. Genetic and phenotypic relationships among milk yield and somatic cell count before and after clinical mastitis. J. Dairy Sci. $88: 827-833$

Liang, K., and S. Zeger. 1986. Longitudinal data analysis using generalized linear models. Biometrika 73:13-22.

Mark, T., and P. G. Sullivan. 2006. Multiple-trait multiple-country genetic evaluations for udder health traits. J. Dairy Sci. 89:48744885 .

McDaniel, B., and R. Adkinson. 1993. Regression of incidence of clinical mastitis on sire evaluations for somatic cell score. J. Dairy Sci. 76(Suppl. 1):238. (Abstr.)

Miglior, F., B. L. Muir, and B. J. Van Doormaal. 2005. Selection indices in Holstein cattle of various countries. J. Dairy Sci. $88: 1255-1263$.

Mrode, R., and G. Swanson. 1996. Genetic and statistical properties of somatic cell count and its suitability as an indirect means of reducing the incidence of mastitis in dairy cattle. Anim. Breed. Abstr. 64:847-857.

Oliver, S. P., and L. M. Sordillo. 1988. Udder health in the periparturient period. J. Dairy Sci. 71:2584-2606.

Paape, M., B. Poutrel, A. Contreras, J. Marco, and A. Capuco. 2001. Milk somatic cells and lactation in small ruminants. J. Dairy Sci. 84(E Suppl.):E237-E244.

Parker, K. I., C. Compton, F. M. Anniss, A. Weir, C. Heuer, and S. McDougall. 2007. Subclinical and clinical mastitis in heifers following the use of a teat sealant precalving. J. Dairy Sci. 90:207-218.

Philipsson, J., G. Ral, and B. Berglund. 1995. Somatic cell count as a selection criterion for mastitis resistance in dairy cattle. Livest. Prod. Sci. 41:195-200.

Piepers, S., L. De Meulemeester, A. de Kruif, G. Opsomer, H. W. Barkema, and S. De Vliegher. 2007. Prevalence and distribution of mastitis pathogens in subclinically infected dairy cows in Flanders, Belgium. J. Dairy Res. 74:478-483. 
Robert-Granie, C., J. Foulley, E. Maza, and R. Rupp. 2004. Statistical analysis of somatic cell scores via mixed model methodology for longitudinal data. Anim. Res. 53:259-273.

Rupp, R., F. Beaudeau, and D. Boichard. 2000. Relationship between milk somatic-cell counts in the first lactation and clinical mastitis occurrence in the second lactation of French Holstein cows. Prev. Vet. Med. 46:99-111.

Rupp, R., and D. Boichard. 2003. Genetics of resistance to mastitis in dairy cattle. Vet. Res. 34:671-688.

Rupp, R., D. Boichard, A. Barbat, J. Astruc, G. Lagriffoul, and F. Barillet. 2002. Selection for mastitis resistance in French dairy sheep. Proc. 7th Congr. Genet. Appl. Livest. Prod. 31:119-122.

Rupp, R., G. Lagriffoul, J. M. Astruc, and F. Barillet. 2003. Genetic parameters for milk somatic cell scores and relationships with production traits in French Lacaune dairy sheep. J. Dairy Sci. $86: 1476-1481$.

Schalm, O., O. William, E. Carroll, and N. Jain. 1971. Bovine Mastitis. Lea and Febiger, Philadelphia, PA.
Snell-Castro, R., J. Godon, J. Delgenes, and P. Dabert. 2005. Characterisation of the microbial diversity in a pig manure storage pit using small subunit rDNA sequence analysis. FEMS Microbiol. Ecol. 52:229-242.

Stear, M. J., S. C. Bishop, B. A. Mallard, and H. Raadsma. 2001. The sustainability, feasibility and desirability of breeding livestock for disease resistance. Res. Vet. Sci. 71:1-7.

Weller, J., A. Saran, and Y. Zeliger. 1992. Genetic and environmental relationships among somatic cell count, bacterial infection, and clinical mastitis. J. Dairy Sci. 75:2532-2540.

Wolfinger, R., and M. O'Connell. 1993. Generalized linear mixed models a pseudo-likelihood approach. J. Statist. Comput. Simul. 48:233-243.

Ziluaga, I., M. Romeo, and J. Marco. 1998. Prevalence, pathogenicity and epidemiology of microorganisms implicated in mastitis processes of sheep. Ovis 59:27-49. 